\title{
An Assessment of Real-World Driving Emissions and Fuel Consumption of a Diesel Bus with Using a Portable Emissions and Fuel Consumption Measurement System: İstanbul Bus Rapid Transit-Metrobus
}

\author{
Portatif Emisyon ve Yakıt Tüketimi Ölçüm Sistemi Kullanılarak Bir Dizel Otobüsün Gerçek \\ Dünya Sürüş Emisyonlarl ve Yakıt Tüketiminin Değerlendirilmesi: Istanbul Otobüs Hızlı \\ Ulaşımı - Metrobus
}

Orkun ÖZENER*

Ylldiz Technical University, Faculty of Mechanical Engineering, Department of Mechanical Engineering, Automotive Sciences Subdivision, 34349, İstanbul

• Geliş tarihi / Received: 14.09.2018 • • Düzeltilerek geliş tarihi / Received in revised form: 20.04.2019 • Kabul tarihi / Accepted: 30.04 .2019

\begin{abstract}
Pollutants from combustion engine powered public transportation are showing great importance in terms of air quality, human being health and also the global warming. The amount of fuel consumed during transportation is another factor that should be taken in to account because of economic aspects. In this context, a part of one of the world's biggest public transportation axle - Istanbul Metrobus public transportation system - which is using a dedicated line is analyzed via using on board emission measurement system and onboard fuel consumption metering devices. The relevant controller area network data was collected during cruises. The fuel consumption and emissions results are analyzed regarding to cruise statistical data, driving modes, road gradient and vehicle specific power data and per passenger statistic. A strong correlation between vehicle specific power and fuel consumption and emissions is shown. The effect of acceleration and velocity are analyzed. Fuel consumption and emission data obtained regarding to the topography indicated that, topography should be used with vehicle properties in public transportation planning. Also it was evaluated that the portable emission measurement systems and mobile fuel consumption measurements can be a part of engine calibration development for environmentally friendly and economic public transportation.
\end{abstract}

Keywords: Driving modes, Fuel consumption, Real driving emissions, Road grade, Vehicle specific power

\section{$\ddot{\boldsymbol{O}} \boldsymbol{z}$}

Içten yanmalı motorlarla tahrik edilen toplu taşıma kaynaklı emisyonlar hava kirliliği, insan sağllğg ve küresel ısınma açısından oldukça önem arz etmektedir. Toplu taşıma esnasında tüketilen yakıt miktarı özellikle ekonomiklik anlamında dikkate alınması gereken diğer bir faktördür. Bu doğrultuda dünya toplu taşıma sisteminin önemli taşıma akslarından biri olan ve kendine ayrılmış özel bir hat kullanan İstanbul Metrobüs Taşıma Sisteminin bir kısmı araç üstü portatif emisyon ve yakıt tüketimi ölçüm cihazları kullanılarak analiz edilmiş ve değerlendirilmiştir. Tüm çalışma boyunca yolcu otobüslerinin elektronik kontrol ă̆ üzerindeki gerekli veriler de paralel olarak toplanmıştır. Sonrasında yakıt tüketimi ve emisyon verileri, seyirlerin istatistiki verileri, sürüş modlarl, yol eğimi ve araç özgül gücü anlamında değerlendirilmiştir. Çalışmada yapılan analizlerle taşıt özgül gücü ile yakıt tüketimi ve emisyonlar arasında güçlü bir korelasyon olduğu gösterilmiştir. İvmenin ve taşıt hızının yakıt tüketimi ve emisyonlar üzerine etkileri irdelenmiştir. Topoğrafyaya bağll elde edilen yakıt tüketimi ve emisyon verileri, toplu taşıma planlamasında topoğrafya verilerinin araç özellikleri ile birlikte kullanımının gerekliliğini ortaya koymuştur. Yapılan analiziler neticesinde araç üstü portatif emisyon ölçüm sistemleri ve mobil yakıt tüketimi ölçüm cihazlarının daha çevreci ve ekonomik toplu taşıma için motor kalibrasyon proseslerinin bir parçası olabileceği değerlendirilmiştir.

Anahtar kelimeler: Sürüş modları, Yakıt tüketimi, Gerçek sürüş emisyonlarl, Yol eğimi, Taşıt özgül gücü

\footnotetext{
* Orkun ÖZENER; oozener@yildiz.edu.tr; Tel: (0532) 70683 66; orcid.org/0000-0001-9168-5161
} 


\section{Introduction}

Pollutants produced from internal combustion engines which are the main power of the vehicles are showing a great interest for scientific and industrial community researchers for long years. They are showing importance in terms of air quality, human being health and also the global warming. The emission from internal combustion engine powered vehicles were restricted with the regulations that is based on laboratory based measurements for a long time. The driving cycles are developed for light duty vehicles and applied on chassis dynamometer tests and emissions in $\mathrm{g} / \mathrm{km}$ based are assessed (Duarte et al., 2016). For heavy duty vehicles the engine rotation per minute (rpm) and engine load trajectory of these cycles are applied on engine dynamometer tests and the results are evaluated in terms of $\mathrm{g} / \mathrm{kWh}$ (Myung et al., 2013). Then it was noted that, on real driving conditions pollutants measured are exceeding the emission measured in laboratory conditions and real driving emissions (RDE) testing and legislations are introduced for vehicles (URL-1, 2017, URL-2, 2018). The RDE is important to reduce the gap between type-approval emissions results and those in the real-world so that vehicles driving on the public roads deliver low emissions as is meant by the legislation. With the introducing of RDE the real road conditions itself become a new environment for testing. The modern laboratory test facilities used for type approval are designed for lessening the effect of all possible external influences, so their reproducibility rates are very high. On the other hand, comparing with these laboratory conditions the real life testing would be never $100 \%$ reproducible. The road gradient, traffic and ambient conditions as well as the characteristics of the driver will influence the results significantly. So the statistical methods and graphs are used frequently for analyzing the results.

The greenhouse gas emissions of the EU transport activity increased by $13.3 \%$ from 1990 to 2014 and they are now the second-largest source of emissions after the energy sector (Andrés and Padilla, 2018). Hence the European Union (EU) is planning to decrease emissions from road transportation to its half to the year 2050. Also the Euro VI emission regulation foresees a huge reduction in both, nitrogen oxides $\left(\mathrm{NO}_{\mathrm{X}}\right)$, carbon monoxide (CO), and particulate matter (PM). The limits for $\mathrm{NO}_{\mathrm{X}}$ reduced $80 \%$ and $77 \%$ for steady state testing and transient testing respectively. Also the limit for PM limits reduced 50\% and 66 for steady state testing and transient testing respectively too. Also at the latest phase of Euro VI regulation presented the requirements for checking and demonstrating the conformity of inservice (ISC) engines and vehicles using Portable Emission Measurement Systems (PEMS) (ICCT, 2016). The EU Regulation 582/2011 (Annex II) provides detailed description of the requirements for the operating compliance evaluation for engines or vehicles.

In this context, the public transportation which using intracity lines during its operation is showing a great importance where there are large concentrations of people is living. The EU share of busses in all the heavy duty vehicle (HDV) fleet is $11 \%$ while the predicted total fuel consumption accounts $15 \%$ of the total fuel consumption of all HDVs (Merkisz and Rymaniak, 2017).Today, the propulsion technologies used in the bus sector are highly diversified. But the 2013 EU bus fleet breakdown shows that $79 \%$ of the fleet is still propelled with diesel fuel combustion engines (UITP, 2014).

There is an extended literature about RDE published especially at last 15 years. Yu and $\mathrm{Li}$ (2014) studied on RDE generated near the bus stops, they proposed that $20 \%$ of the pollutants was emitted near bus stops, and $30 \%$ at road intersection segments and $50 \%$ at the links. Joumard et al. (2003) studied the vehicle load relationship with RDE with using average speed and load term. They found that the emissions are generated like an $\mathrm{U}$ shape curve regarding to the average speed and also the increase at loading is resulted as decrease in real driving $\mathrm{CO}, \mathrm{HC}$ and $\mathrm{PM}$ emissions while the opposite effect is found for real driving $\mathrm{NO}_{\mathrm{X}}$ emission and real driving $\mathrm{CO}_{2}$. Zhang et al. (2016) worked on RDE of heavy duty vehicles. They showed the emission levels in acceleration conditions was significantly higher than of deceleration conditions. They explained this phenomenon with the sudden acceleration demands results with incomplete combustion so the greater emission rates. They also found that gaseous emissions are increasing with the increase of Vehicle Specific Power (VSP). Choudhary and Gokhale (2016) studied emissions, the emissions from vehicles during peak and off-peak hours. They found sharp increases in acceleration and deceleration are the main cause of the generated emissions. Yao et al. (2013) studied statistical vehicle specific power profiling at urban freeways. They proposed that the grade and speed is important in vehicle specific power profiling. Mendoza-Villafuerte et 
al. (2017) carried a comprehensive research on real time emissions, they found that found that the highest real driving $\mathrm{NO}_{\mathrm{X}}$ emissions were measured during urban operation which is of great concern for urban air quality. They also concluded the cold start emission share for $\mathrm{NO}_{\mathrm{X}}$ is considerably high. Hao et al. (2017) developed a model using a RDE database to predict low speed vehicles, Lujan et al. (2018) studied on-board gaseous emissions measurements from a Euro 6 light-duty diesel vehicle, they confirmed that lower speed with higher rate of acceleration and deceleration lead to higher real driving $\mathrm{NO}_{\mathrm{X}}$ emissions compared to higher speeds. Wang et al. (2011) made RDE measurements with Beijing Busses. They found that all factors both for fuel and emissions are all decreased when the vehicle speed is increased. They also concluded that when the acceleration is increased the factors are also increased and the effect of deceleration was found less significant. Lastly they reported a strong correlation between the emissions, fuel consumption and VSP.

In this context, one of the world biggest transportation axle, Istanbuls' most important public transportation line - Metrobus Line, named as first intercontinental bus rapid transit by Alpkokin and Ergun (2012) - was chosen as the research area for identifying RDE from compression ignition (CI) engines that is used public transportation area. Metrobus Line is a dedicated transit bus line which crosses the İstanbul city from Asia to Europe (Çakır and Akbayir 2017). Its length is about 52 kilometers totally and there is more than 550 busses in $24 \mathrm{~h}$ service. The line enables mass transit transport $\sim 1$ Million passenger daily between two continents. The real public bus used in this research. The test bus is equipped with portable emission measurement devices (PEMS) for collecting RDE data, and portable fuel consumption meter (PFCM) for collecting fuel consumption data and a controller area network (CAN) logger that is connected to bus electronic network for collecting the relevant data. Then the analyses regarding to driving modes and vehicle specific power were carried with collected data and alternative scenarios for decreasing emissions and fuel consumption are discussed.

\section{Methods}

\subsection{Measurement System}

A Euro 5 public bus which is powered by a diesel engine was used for measurements. The vehicle properties are given at Table 1. The fuel consumption measurements were made with AVL KMA Mobile instrument. For real driving carbon dioxide $\left(\mathrm{CO}_{2}\right)$ and emission $\left(\mathrm{NO}_{\mathrm{X}}, \mathrm{CO}\right.$, Soot $)$ measurements the AVL MOVE system was used. The properties of measurement system and the methods that devices for measuring and accuracies are given at Table 2. The position of the vehicle was monitored at $2 \mathrm{~Hz}$ GPS equipment. The actual torque, accelerator pedal position, gear, and wheel based vehicle speed data was logged with CAN logger device. The measurement system and its configuration are presented in Figure 1.

Table 1. Properties of vehicle and engine

\begin{tabular}{ll}
\hline Vehicle Weight & 32 tones \\
Type of bus & Articulated \\
Length of Vehicle & $18 \mathrm{~m}$ \\
Number of cylinders & 6 \\
Engine capacity & 11.9 liters \\
Power & $@ 2000 \mathrm{rpm}-260 \mathrm{~kW}$ \\
Torque & $@ 1100 \mathrm{rpm}-1600 \mathrm{Nm}$ \\
Compression Ratio & $17.75: 1$ \\
\hline
\end{tabular}

Table 2. Properties of measurement system

\begin{tabular}{|c|c|c|c|}
\hline System & Device & Method & Accuracy \\
\hline $\begin{array}{l}\text { Fuel } \\
\text { Consumption }\end{array}$ & KMA Mobile-AVL & $\begin{array}{l}\text { Rotational type servo positive displacement flowmeter } \\
\text { (PLU) }\end{array}$ & $\pm 0.1 \%$ \\
\hline \multirow[t]{5}{*}{ Emission } & Gas PEMS-AVL & $\mathrm{NO} \rightarrow \mathrm{UV}^{-R A S}{ }^{i}$ & $\pm 0.2 \%$ \\
\hline & & $\mathrm{NO}_{2} \rightarrow \mathrm{NDUV}^{i}$ & $\pm 0.2 \%$ \\
\hline & & $\mathrm{O}_{2} \rightarrow$ Oxygen Sensor & $\pm 1 \%$ \\
\hline & & $\mathrm{CO} \rightarrow \mathrm{NDIR}^{i i}$ & $\pm 30 \mathrm{ppm}$ \\
\hline & & $\mathrm{CO}_{2} \rightarrow \mathrm{NDIR}$ & $\pm 0.1 \%$ \\
\hline Emission & PM Pems-AVL & Soot $\rightarrow$ Photoacoustics & $\sim 5 \mu \mathrm{g} / \mathrm{m}^{3}$ \\
\hline $\begin{array}{l}{ }^{i} \text { NDUV } \\
{ }^{i i} \text { NDIR } \\
\end{array}$ & $\begin{array}{l}\text { ersive Ultraviolet } \\
\text { ersive Infrared }\end{array}$ & & \\
\hline
\end{tabular}



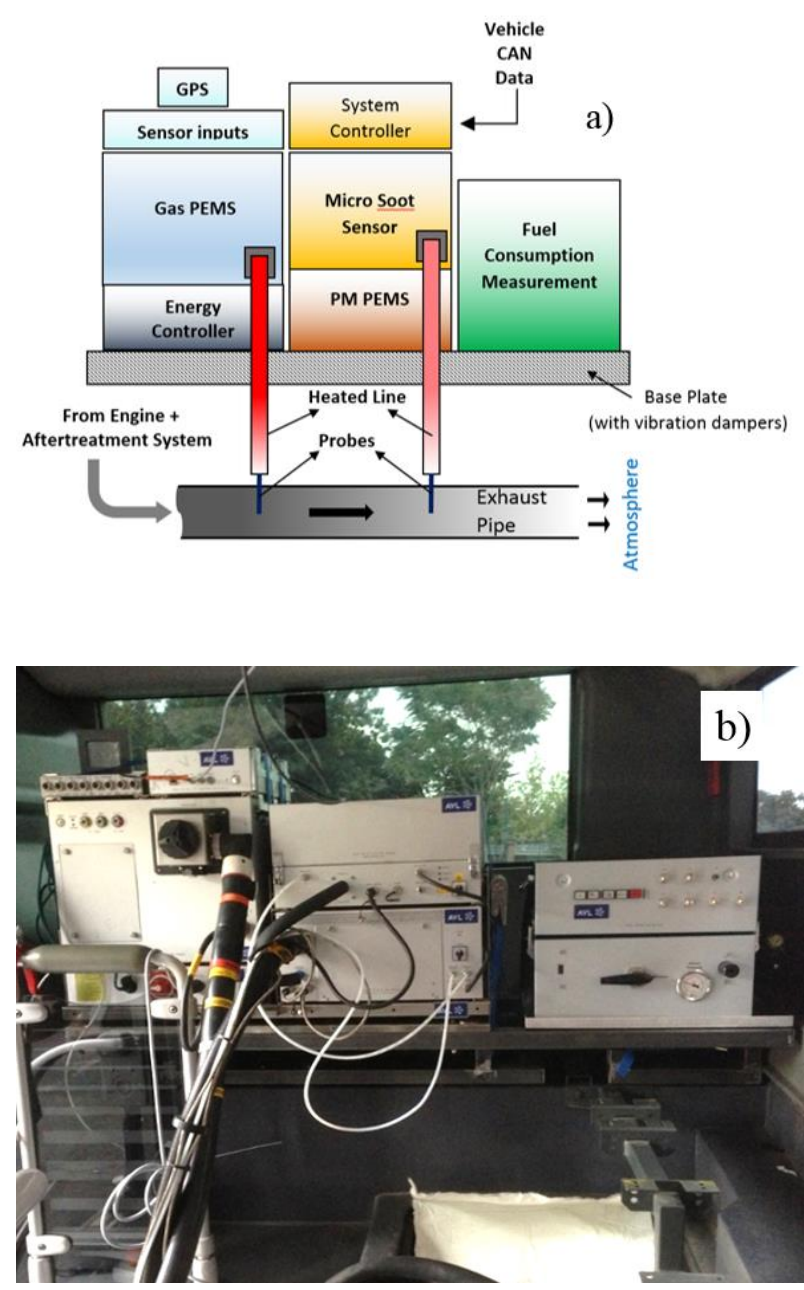

Figure 1. a) Test system layout and b) Test system set-up

\subsection{Test Route and Vehicle Load}

The Metrobus line is consisting of 3 main parts. First part is Sögütlüçeşme to Zincirlikuyu direction it includes 8 stations and the length is 11 $\mathrm{km}$. The second part is Zincirlikuyu to Avcilar direction. It is the longest part with $29 \mathrm{~km}$ length and 25 stations. The last part is Avcilar to Beylükdüzü direction. The length of this part is 16 $\mathrm{km}$ and the number of stations is 12 . The tests for this research was carried on Avc1lar (A) to Beylikdüzü (B) direction ( $\mathrm{AB}$ ) which is called 34B route by İstanbul Public Transportation Company (IETT) .The reason of choosing this part of the line is, this part has the maximum altitude change (173 meters) during in its operation. It enables to evaluate the interaction between altitude change, RDE, fuel consumption and other operating parameters. The test route is given Figure 2. For simulating the passenger weight, the vehicle is loaded with 13 tons of sandbag which is the maximum allowable capacity of the bus. This payload condition is called as full load (FL) herein after.

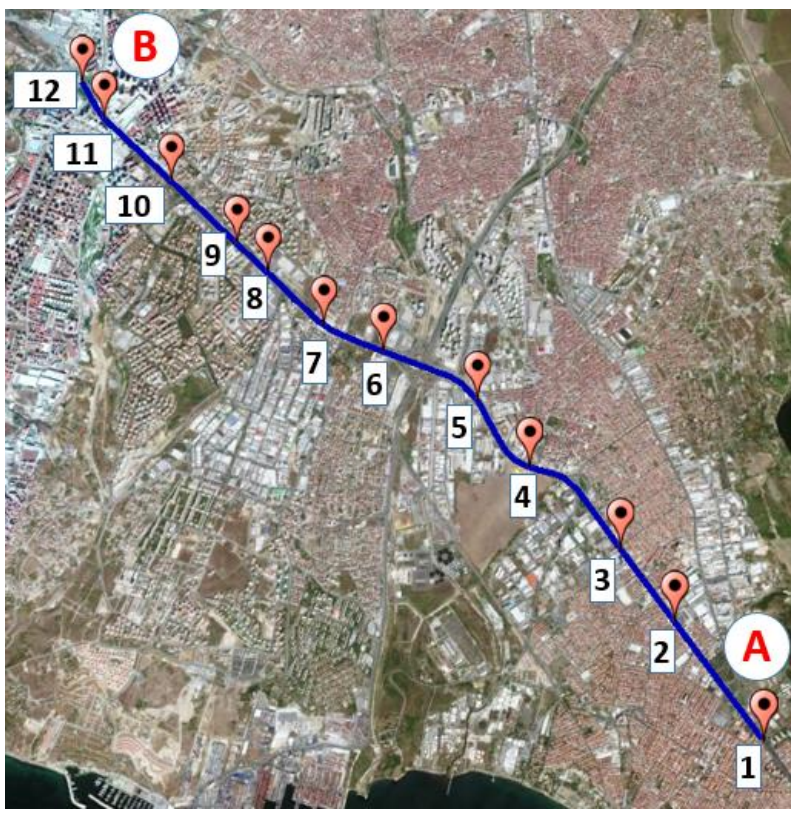

Figure 2. Google Earth image of test route

\subsection{Vehicle Specific Power Identification}

Vehicle specific power (VSP) is a term that is representing instantaneous power per unit mass of vehicle. It was developed by Jimenez-Palacios (1999). The idea is using the generated power by the engine to overcome rolling resistance and aerodynamic drag and to increase the kinetic and potential energies of the vehicle. The used unit for VSP is kilowatt / Tones $(\mathrm{kW} / \mathrm{T})$. The formula is given as;

$V S P=\frac{\text { Power }}{\text { Mass }}=\frac{F_{t}}{m}=\frac{\left(F_{r}+F_{w}+F_{g}+F_{a}\right) v}{m}$

where, " $F_{r}$ " is representing rolling resistance, " $F_{w} "$ is representing wind resistance, " $F_{g}$ "representing gradient resistance and " $F_{a}$ " is representing the acceleration resistance

$V S P=\frac{\left(m g f \cos \alpha+0.5 \rho_{a} C_{d} A\left(v+v_{m}\right)^{2}+m g \sin \alpha+\left(1+\varepsilon_{i}\right) \cdot m \cdot a\right) v}{m}$

where " $m$ " is the total net mass with passenger and all loads $(\mathrm{kg})$, " $g$ " is gravity $-9.81 \mathrm{~m}^{2}$, " $f$ " is dimensionless rolling resistance coefficient (0.00938), " $\alpha$ " is gradient angle, " $\rho_{a}$ " air density $1.226 \mathrm{~kg} / \mathrm{m}^{3}$, " $C_{d}$ " is dimensionless coefficient of aerodynamic drag (0.6), " $A$ " aerodynamic reference frontal area $\left(7 \mathrm{~m}^{2}\right)$, " $v_{m}$ " is the crosswind heading to the bus assumed as $(0 \mathrm{~m} / \mathrm{sn})$ " $a$ " acceleration of the bus $\left(\mathrm{m} / \mathrm{s}^{2}\right)$, " $\varepsilon_{i}$ " dimensionless mass factor (0.1) (Yu et al. 2016) and " $v$ "is the vehicle speed $(\mathrm{m} / \mathrm{sn})$. The simplified version of correlation is given in equation 3 . 
$V S P=v\left[g f+g \sin \alpha+\left(1+\varepsilon_{i}\right) \cdot a\right]+$ $0.5 \rho_{a} \frac{C_{d} A}{m}\left(v+v_{m}\right)^{2} v$

\section{Results and Discussion}

\subsection{Effect of Altitude Change}

The fuel consumption and real driving $\mathrm{CO}_{2}$ and emission changes with the altitude for $\mathrm{AB}$ and $\mathrm{BA}$ direction at FL condition is given in Figure 3 a-e. It can be seen from the figure the fuel consumption rates at $\mathrm{AB}$ direction is higher than the BA direction which can be explained with a high altitude change. It is also obvious that for BA direction trips the fuel consumption is becoming frequently at very low rates which is because of fuel cut off strategy of bus engine control system which is a reason of downhill characteristics of BA direction. The same behavior can be easily detected for real driving $\mathrm{CO}_{2}$ which the characteristics are similar with fuel consumption. The real driving $\mathrm{NO}_{\mathrm{X}}, \mathrm{CO}$ and soot emission rates are also exhibiting same behavior, but the amount of gaseous and both particulates seems to be higher especially at takeoffs from stations which is followed by an acceleration section to reach the cruising speed. The results are quite harmonious with the research that was made by Prati et al. (2015).
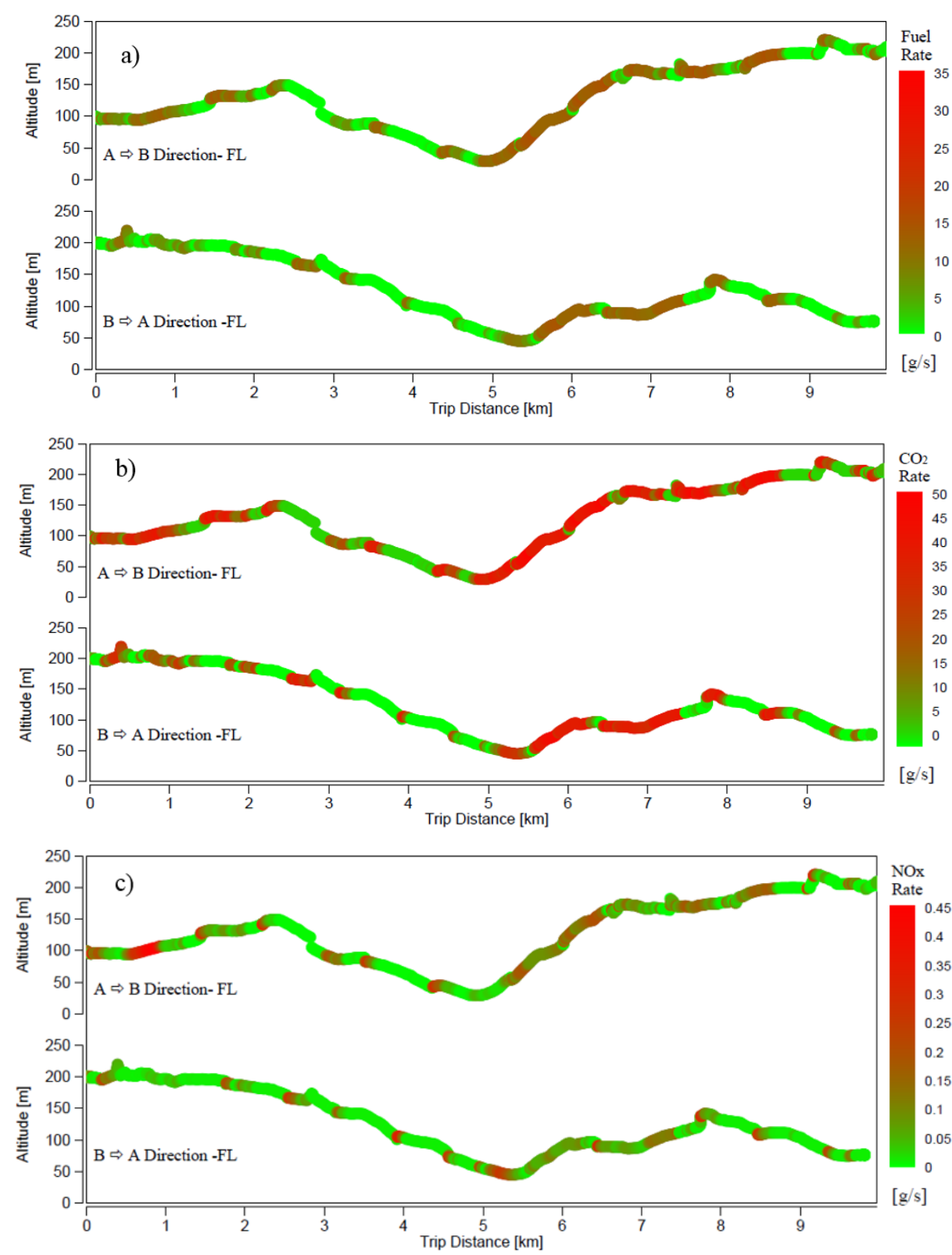

Figure 3 Continued 

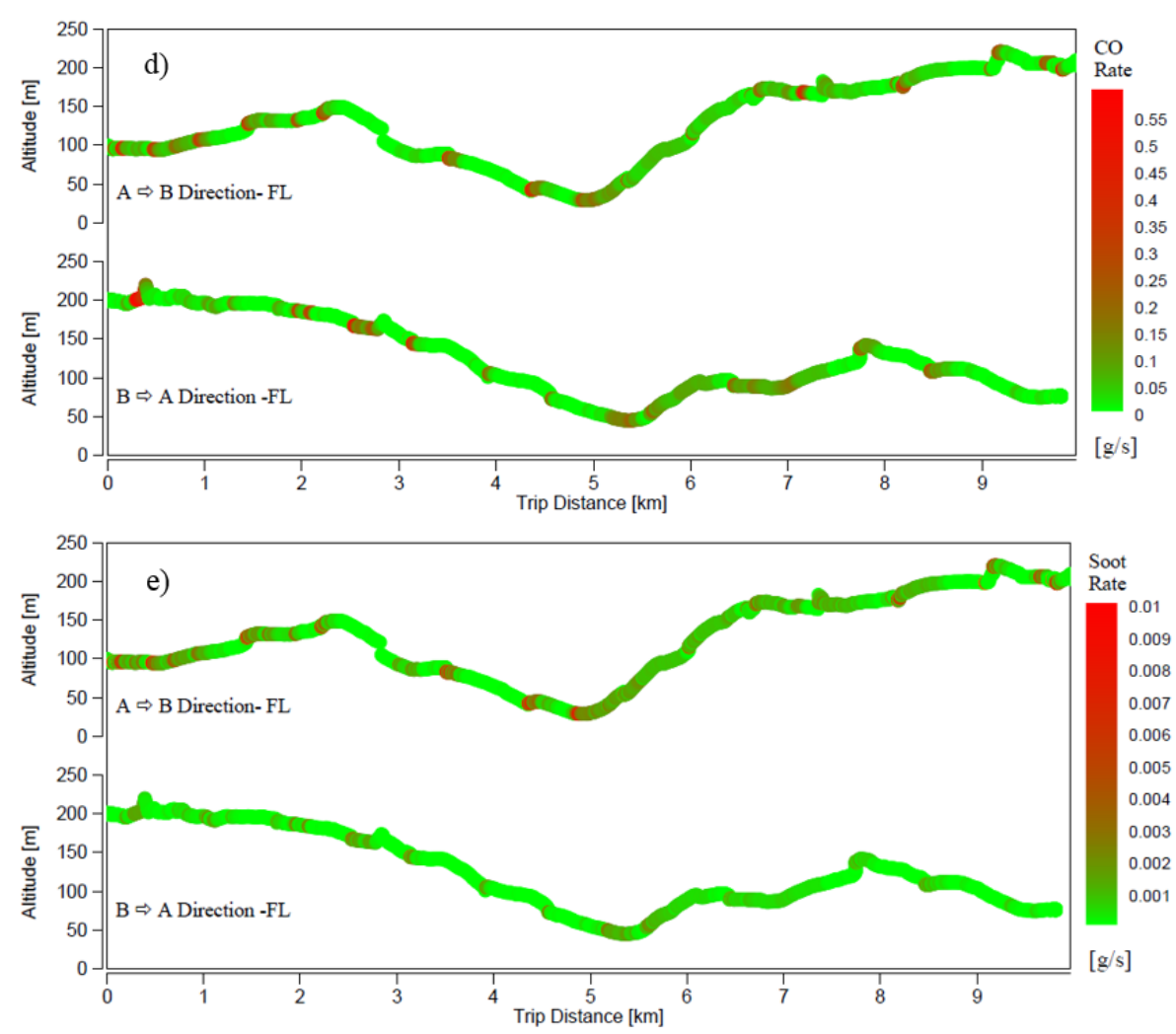

Figure 3. Fuel consumption and real driving $\mathrm{CO}_{2}$ and emission rates in mass basis (g/s) regarding to altitude. a) Fuel rate change b) $\mathrm{CO}_{2}$ rate change c) $\mathrm{NO}_{\mathrm{X}}$ rate change d) $\mathrm{CO}$ rate change e) Soot rate change

\subsection{Vehicle Specific Power (VSP) Analysis}

As it is indicated VSP definition is presenting the power demand of the engine per unit vehicle mass. The VSP analysis, calculated with the method given section 2.3 for fuel consumption, gaseous emissions and total energy consumed regarding to VSP modes at $\mathrm{AB}$ and $\mathrm{BA}$ direction FL conditions are given in Figure 4 a-e.
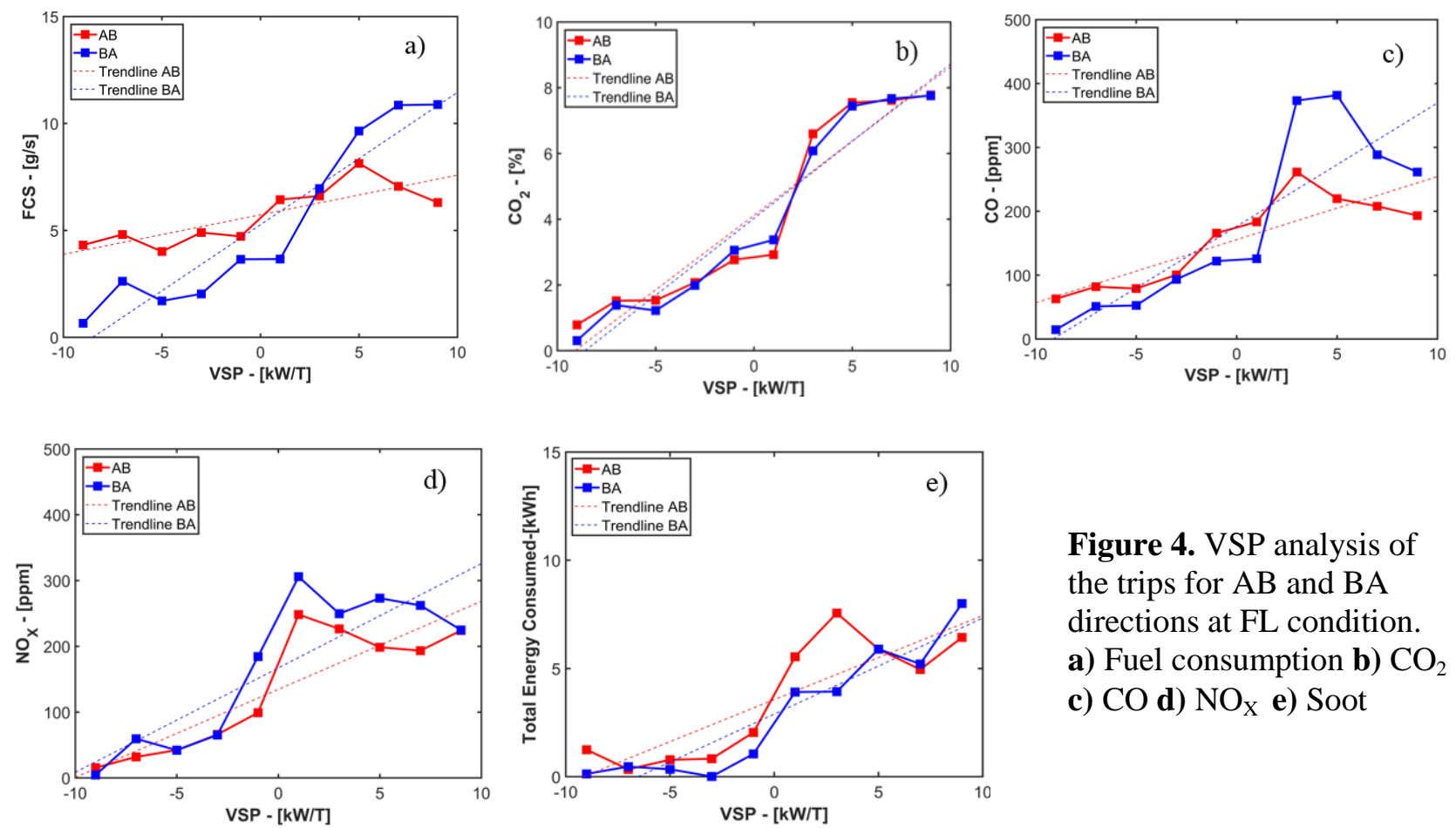

Figure 4. VSP analysis of the trips for $\mathrm{AB}$ and $\mathrm{BA}$ directions at FL condition.

a) Fuel consumption b) $\mathrm{CO}_{2}$

c) $\mathrm{CO}$ d) $\mathrm{NO}_{\mathrm{X}}$ e) Soot 
The results are binned for VSP groups and then the binning groups are averaged for fuel consumption (FCS), real driving $\mathrm{CO}_{2}$ and emissions. For total energy consumption the cumulative of these bins are used. It is obvious from the Figure 4 that the measured emissions in $\mathrm{kw} / \mathrm{T}$ is increasing with the increase of VSP and when the VSP is becoming lower than zero both fuel consumption and emissions are lowered considerably. Same trend was observed for total energy consumption. Thus this results shows that there is strong correlation with fuel consumption and emissions (Wang et al., 2011).

\subsection{Driving Mode Analysis}

For driving modes analysis the vehicle velocity and acceleration level bin distributions are analyzed at first. The normalized results for $\mathrm{AB}$ and $\mathrm{BA}$ direction at FL condition for all three test of this research are given in Figure 5. As it's seen from the figure the acceleration level between 0 and $0.5 \mathrm{~m} / \mathrm{s}^{2}$ is the zone which has the highest frequency for all velocity zones. The highest frequency is realized at speeds between $0-10 \mathrm{~km} / \mathrm{h}$ at $0-0,5 \mathrm{~m} / \mathrm{s}^{2}$ which the rates is accounts nearly $15 \%$ percent for all loading conditions.
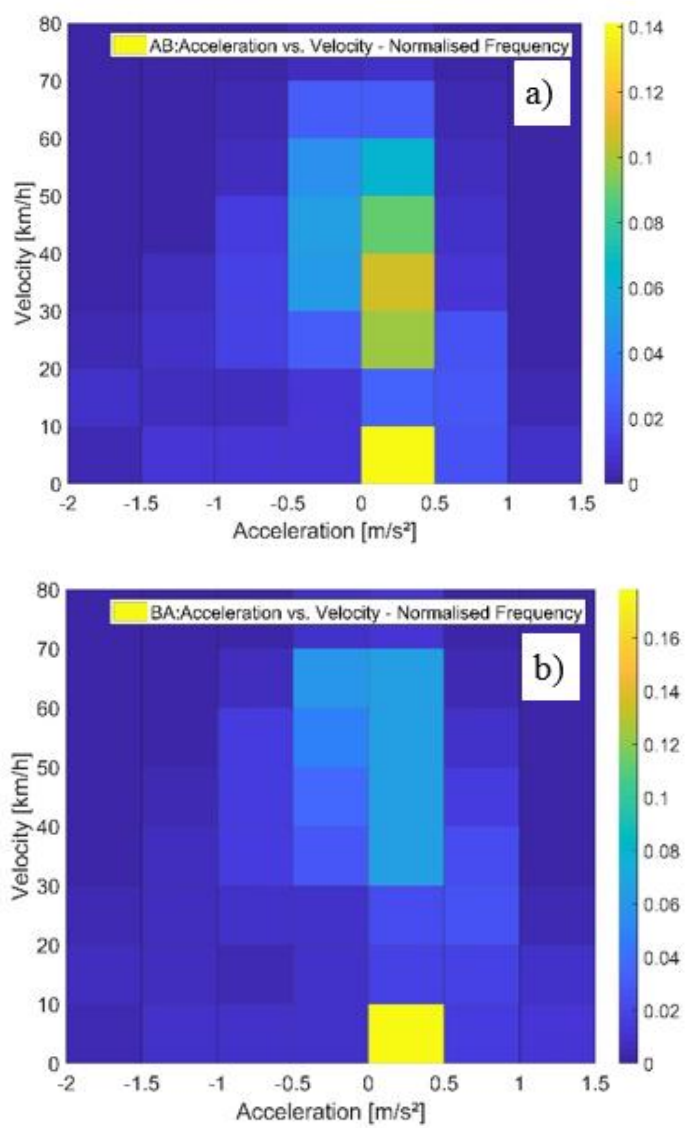

Figure 5. Velocity acceleration distributions. a) AB Direction b) BA Direction
In this context the velocity/speed and acceleration are divided in to modes for analyzing the effect of driving modes on both fuel consumption and emissions. The speed modes (SPM) are identified as with $10 \mathrm{~km} / \mathrm{h}$ increments starting from stop conditions. Also the acceleration levels are divided with $0.5 \mathrm{~m} / \mathrm{s}^{2}$ increments acceleration modes (ACM) are identified. Identified modes detail is given Table 3 and Table 4.

Table 3. Speed modes

\begin{tabular}{llllccccc}
\hline & \multicolumn{7}{c}{ Speed Modes } \\
\cline { 2 - 8 } MODE & $\mathbf{1}$ & $\mathbf{2}$ & $\mathbf{3}$ & $\mathbf{4}$ & $\mathbf{5}$ & $\mathbf{6}$ & $\mathbf{7}$ & $\mathbf{8}$ \\
\hline $\begin{array}{l}\text { Upper } \\
\text { Limit } \\
(\mathrm{km} / \mathrm{h})\end{array}$ & 10 & 20 & 30 & 40 & 50 & 60 & 70 & 80 \\
\hline $\begin{array}{l}\text { Lower } \\
\text { Limit } \\
(\mathrm{km} / \mathrm{h})\end{array}$ & 0 & 10 & 20 & 30 & 40 & 50 & 60 & 70 \\
\hline
\end{tabular}

Table 4. Acceleration modes

\begin{tabular}{llllllll}
\hline & \multicolumn{7}{c}{ Acceleration Modes } \\
\cline { 2 - 8 } MODE & $\mathbf{1}$ & $\mathbf{2}$ & $\mathbf{3}$ & $\mathbf{4}$ & $\mathbf{5}$ & $\mathbf{6}$ & $\mathbf{7}$ \\
\hline $\begin{array}{l}\text { Upper } \\
\text { Limit } \\
\left(\mathrm{m} / \mathrm{s}^{2}\right)\end{array}$ & -1.5 & -1 & -0.5 & 0 & 0.5 & 1 & 1.5 \\
$\begin{array}{l}\text { Lower } \\
\text { Limit } \\
\left(\mathrm{m} / \mathrm{s}^{2}\right)\end{array}$ & -2 & -1.5 & -1 & -0.5 & 0 & 0.5 & 1 \\
\hline
\end{tabular}

The fuel consumption, real driving $\mathrm{CO}_{2}$ and emissions in mass basis shares (fuel consumption at this mode / total fuel consumption $\times 100$ - real driving $\mathrm{CO}_{2}$ at this mode / total real driving $\mathrm{CO}_{2}$ mass- emission mass at this mode / total emission mass $x$ 100) are analyzed regarding to these speed and acceleration. The results for $\mathrm{AB}$ direction at FL condition \% shares are shown in Figure 6. As it seen from the figures the critical mode is ACM5 combined with SPM1 which the highest share of emissions are emitted in this region compared to the cumulative value. Also the negative ACM modes (ACM1-ACM4) cannot be neglected considering to the shares. Which it should be can be taken under control with changing driving style and modifying the engine control strategy if possible. For fuel consumption, real driving $\mathrm{CO}_{2}$ and real driving soot emissions the SPM3 to SPM6 was found critical additional to SPM1 at ACM5 condition. For real driving $\mathrm{CO}$ emissions the negative acceleration modes ACM3 and ACM4 was found critical. It is explained with insufficient in cylinder mixture formation during deceleration phases. For real driving $\mathrm{NO}_{\mathrm{X}}$ 
emissions as it seen from Figure 6-c, ACM5 + SPM1 mode is dominating the share. Nearly half of the $\mathrm{NO}_{\mathrm{X}}$ emission was emitted as this region. Which can be attributed to insufficient $\mathrm{NO}_{\mathrm{X}}$ control strategy of the engine at this condition which usually encountered take offs from the stations. It can be concluded as the emitted $\mathrm{NO}_{\mathrm{X}}$ from cylinder remains at a higher level that that SCR can convert at this operating regime.
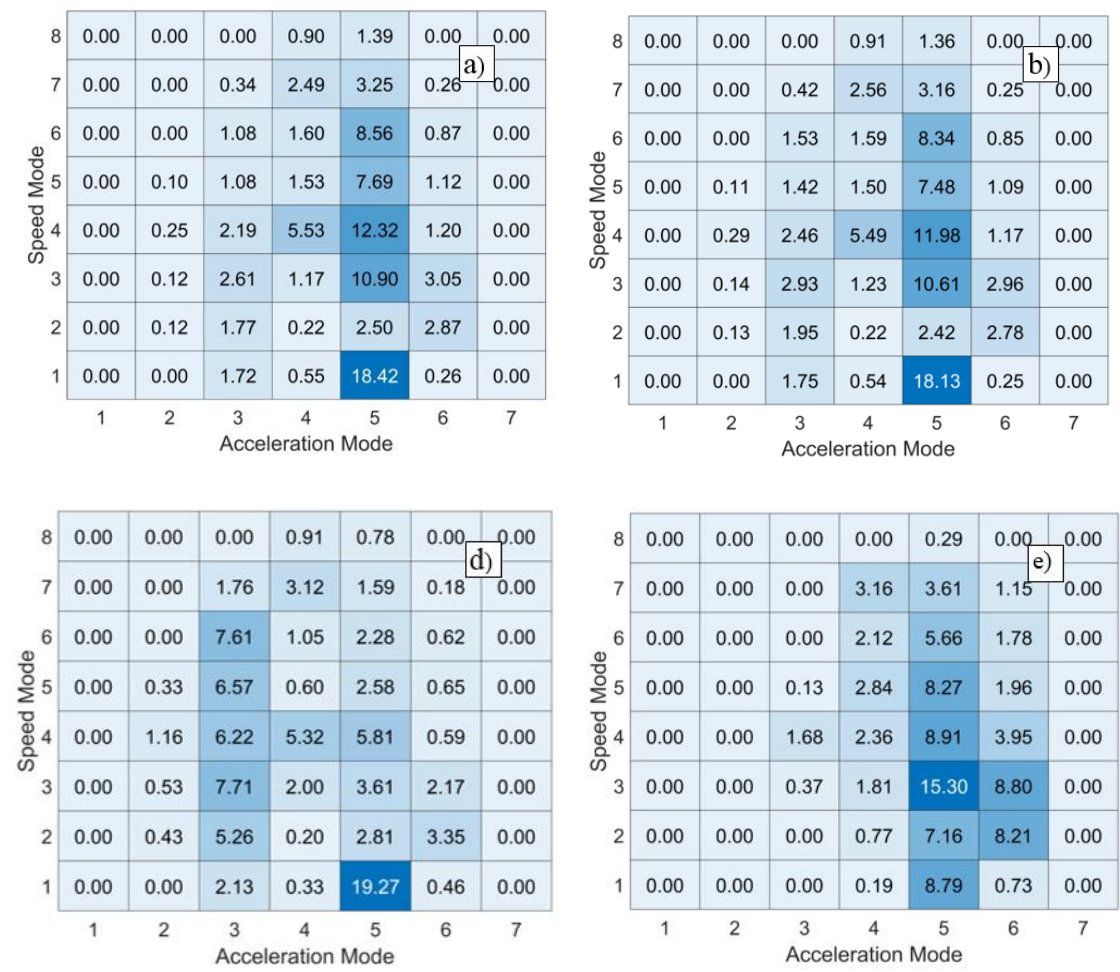

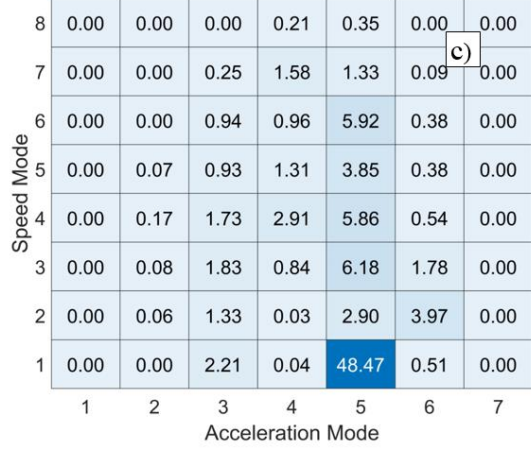

Figure 6. Fuel consumption and real driving $\mathrm{CO}_{2}$ and emission maps with modes at $\mathrm{AB}$ direction a) Fuel consumtpion $\%$ share b) $\mathrm{CO}_{2}$ $\%$ share c) NOX emission $\%$ share d) $\mathrm{CO}$ emission $\%$ share e) SOOT emission $\%$ share

\subsection{Fuel Consumption and Real Driving $\mathrm{CO}_{2}$ and Emissions Contour Analysis}

For analyzing the characteristics of the fuel consumption, real driving $\mathrm{CO}_{2}$ and emissions with an extended perspective the time based mass basis $(\mathrm{g} / \mathrm{s})$ contour graphs regarding to acceleration and velocity is given in Figure 7 for BA direction FL condition. As it is seen from the graphics the positive acceleration zones are playing an important role for both fuel consumption and emissions. The fuel consumption and real driving $\mathrm{CO}_{2}$ reaches their top level after $25 \mathrm{~km} / \mathrm{h}$ hour positive acceleration zones which can be explained with a higher power demand at this region. For real driving $\mathrm{NO}_{\mathrm{X}}$ emissions the critical values are accelerations over $0.5 \mathrm{~m} / \mathrm{s}^{2}$, and velocities between $10-40 \mathrm{~km} / \mathrm{h}$. This can be explained very high power demand and higher in cylinder temperatures and insufficient $\mathrm{NO}_{\mathrm{X}}$ after treatment strategy of the engine at this operating zone. Also a negative acceleration zone was found important for $\mathrm{NO}_{\mathrm{X}}$ 'es. The acceleration between 0 and $-0.5 \mathrm{~m} / \mathrm{s}^{2}$ and velocities between $0-10 \mathrm{~km} / \mathrm{h}$ was found critical for $\mathrm{NO}_{\mathrm{x}}$ emissions which can be explained with engine control system characteristics. The real driving $\mathrm{CO}$ and Soot emissions are also found higher for accelerations higher than $0.5 \mathrm{~m} / \mathrm{s}^{2}$ and velocities between 5 $\mathrm{km} / \mathrm{h}$ and $30 \mathrm{~km} / \mathrm{h}$. This can be explained with heterogonous mixture formation during low speed acceleration phases.

\section{Conclusion}

The public transportation bus working in İstanbul Metrobus line is equipped with PEMS and Mobile Fuel Consumption measurement devices. The analyses showed that;

i) All fuel consumption and emission rates for both directions are developed. The altitude change was found a significant parameter that effect both fuel consumption and emissions as expected. Considering to the vehicle powertrain loading requirements and emission characteristics at high grade take offs from bus stops, it can be concluded as the grade effect and bus stop location choosing algorithm should be clearly identified with using public transport requirements. 

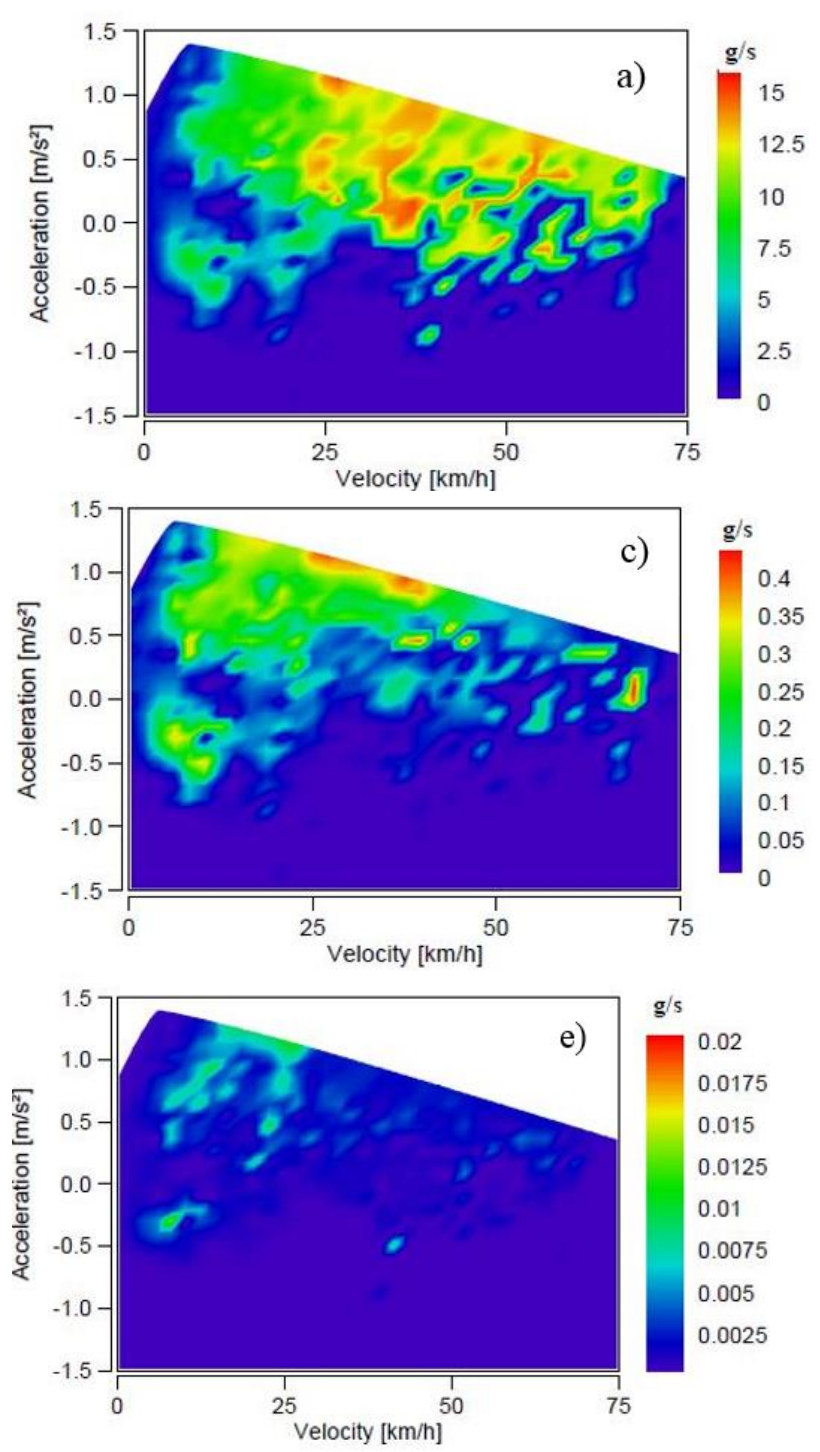

i) The VSP analyses are made for both directions at FL condition. There was a strong correlation was found between fuel consumption, emissions and VSP. The fuel consumption and measured emissions are increased with the increase of VSP. The VSP calculations showed that the VSP approach can be used effectively for public transport planning of new coming routes with alternative speed trajectories. It is possible to make an approach for pollutants and economy of the new routes.

ii) The velocity-acceleration frequency graphics are developed for both directions. It was found that the highest velocityacceleration frequency is realized between $0.5 \mathrm{~m} / \mathrm{s}^{2}$ and $0.5 \mathrm{~m} / \mathrm{s}^{2}$ acceleration levels for all velocities.

iii) The velocity/speed and acceleration regions are divided in to modes. There was 8 speed
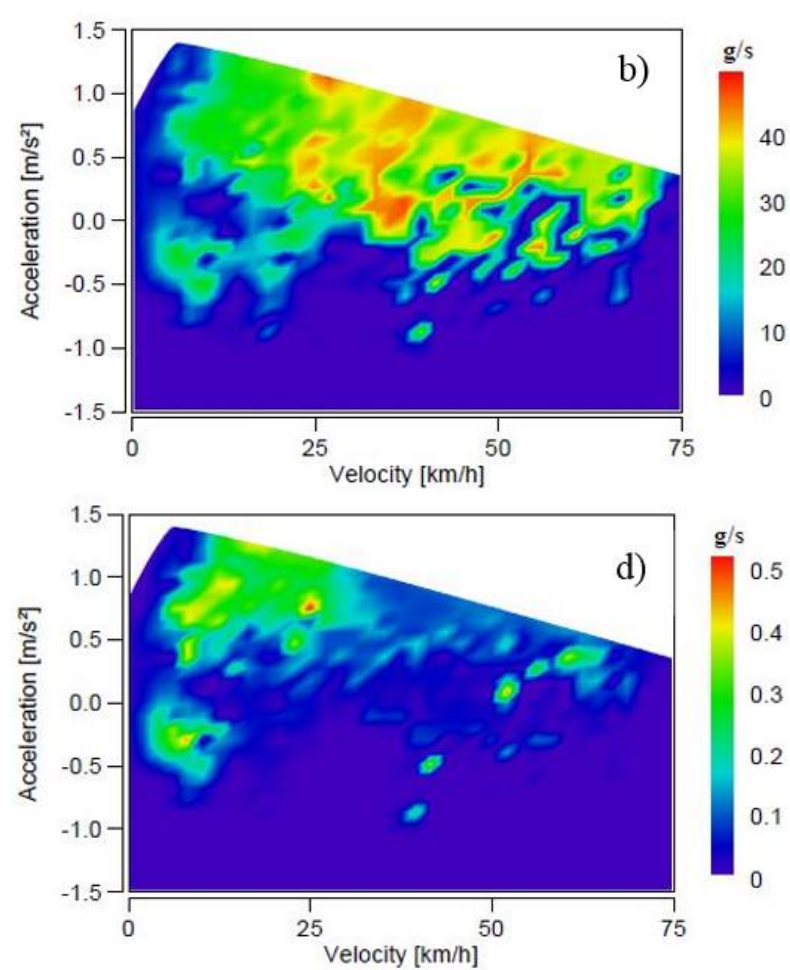

Figure 7. Fuel consumption and real driving $\mathrm{CO}_{2}$ and emission contour graphs at BA direction regarding to acceleration and velocity a) Fuel consumption b) $\mathrm{CO}_{2}$ c) $\mathrm{NO}_{\mathrm{X}}$ d) $\mathrm{CO}$ e) Soot

mode 7 acceleration modes are developed. Fuel consumption and emission are developed analyzed regarding to this modes in mass basis shares compared the total consumed fuel and emissions. The analysis showed that the critical region for cumulative results is lying at low level acceleration at the speeds between 0-40 $\mathrm{km} / \mathrm{h}$ for all types of emissions and fuel consumption.

iv) The contour graphs for fuel consumption and emissions in $\mathrm{g} / \mathrm{s}$ base at BA direction are developed. It was found that the fuel consumption and emissions are increased with the increase of acceleration.

v) For real driving $\mathrm{CO}, \mathrm{NO}_{\mathrm{x}}$ and soot decreasing, the cruises should be realized below the critical positive acceleration level $0.5 \mathrm{~m} / \mathrm{s}^{2}$ for all velocities. Considering to the engine homologation cycles, it can be 
concluded as the emission calibration strategy of public transportation vehicle engine should be carefully developed with taking these real driving and route characteristics.

vi) The real driving $\mathrm{NO}_{\mathrm{x}}$ emissions was found higher especially at low speed $(\mathrm{v}<40 \mathrm{~km} / \mathrm{h})$ positive acceleration zones which can be explained by power demand because of acceleration demand from driver at takeoff session. Even the engine is Euro 5, the emission control system and strategy is insufficient to prevent high $\mathrm{NO}_{\mathrm{X}}$ emitting at this operating regime. So it can be recommended that, changing of emission control strategy or equipment characteristics which are more harmonious with this predefined route or limiting the acceleration at the take of sessions for decreasing the $\mathrm{NO}_{\mathrm{x}}$ emissions by considering the safety concern would be a solution of these phenomena. On the other hand this result show that the standard engine emission calibration strategy with standard equipment are not giving the optimum solution at every route. So it can be concluded as the route and public transportation characteristics should be carefully taken in to consideration into vehicle powertrain control strategies.

vii) The real driving $\mathrm{CO}$ emissions was found higher especially below moderate speeds $(\mathrm{v}<30 \mathrm{~km} / \mathrm{h})$ and positive acceleration higher than $0.5 \mathrm{~m} / \mathrm{s}^{2}$ which can be explained the insufficient mixture formation so the increased rich regions in the combustion chamber during this movement. So for decreasing CO emissions especially the sharp accelerations should be avoided below $30 \mathrm{~km} / \mathrm{h}$.

viii) For fuel consumption and real driving $\mathrm{CO}_{2}$ and emission levels the speed higher than $30 \mathrm{~km} / \mathrm{h}$ was found critical for all positive acceleration levels. In this context it is recommended to avoid sharp acceleration changes higher than $30 \mathrm{~km} / \mathrm{h}$ for cleaner transportation.

This research showed that, it is possible to realize more efficient and cleaner public transport and relevant engine control calibration set with analyzing the real driving data. It was evaluated that the PEMS and Mobile Fuel Consumption measurements can be a part of engine calibration development for environmentally friendly public transportation. All of these parameters should be clearly evaluated and the parameters should be optimized in this context with multi objective approach, taking the arrival timing and safety concerns.

\section{Acknowledgement}

This research was funded by the Istanbul Development Agency -ISTKA, under Information Focused Economic Development Programme, project no. BIL-86 with the partnership of Istanbul Public Transportation Company (IETT).

\section{References}

Alpkokin, P. and Ergun, M., 2012. Istanbul Metrobüs: first intercontinental bus rapid transit. Journal of Transport Geography, 24, 58-66.

Andrés, L. and Padilla, E., 2018. Driving factors of GHG emissions in the EU transport activity. Transport Policy, 61, 60-74.

Çakır, F.H. and Akbayır, Ö., 2017. Metrobüs Sisteminin Enerji Kullanımı ve Çevreye Etkilerinin İncelenmesi, Elektrikli Araçlar ve Trolleybüslerin Kullanım Potansiyellerinin Araştırılması. Mehmet Akif Ersoy Üniversitesi Fen Bilimleri Enstitüsü Dergisi, Özel Sayı 1, 97-102.

Choudhary, A. and Gokhale, S., 2016. Urban realworld driving traffic emissions during interruption and congestion. Transportation Research Part D: Transport and Environment, 43(Supplement C), 59-70.

Duarte, G. O., Gonçalves, G. A. and Farias, T. L., 2016. Analysis of fuel consumption and pollutant emissions of regulated and alternative driving cycles based on real-world measurements. Transportation Research Part D: Transport and Environment, 44, 43-54.

Hao, L., Chen, W., Li, L., Tan, J., Wang, X., Yin, H., Ding, Y. and Ge, Y., 2017. Modeling and predicting low-speed vehicle emissions as a function of driving kinematics. Journal of Environmental Sciences, 55, 109-117.

ICCT, 2016, International Council on Clean Transport, A technical summary of Euro 6/VI vehicle emission standards.

Joumard, R., André, M., Vidon, R. and Tassel, P., 2003. Characterizing real unit emissions for light duty goods vehicles. Atmospheric Environment, 37(37), 5217-5225. 
Luján, J. M., Bermúdez, V., Dolz, V. and MonsalveSerrano, J., 2018. An assessment of the realworld driving gaseous emissions from a Euro 6 light-duty diesel vehicle using a portable emissions measurement system (PEMS). Atmospheric Environment, 174, 112-121.

Mendoza-Villafuerte, P., Suarez-Bertoa, R., Giechaskiel, B., Riccobono, F., Bulgheroni, C., Astorga, C. and Perujo, A., 2017. $\mathrm{NOx}, \mathrm{NH}_{3}$, $\mathrm{N}_{2} \mathrm{O}$ and $\mathrm{PN}$ real driving emissions from a Euro VI heavy-duty vehicle. Impact of regulatory onroad test conditions on emissions. Science of the Total Environment, 609, 546-555.

Merkisz, J. and Rymaniak, L, 2017. Tests of urban bus specific emissions in terms of currently applicable heavy vehicles operating emission regulations. Combustion Engines, 1(168), 2126.

Myung, C.-L., Ko, A., Kim, J., Choi, K., Kwon, S. and Park, S., 2013. Specific engine performance and gaseous emissions characteristics of European test cycle and worldwide harmonized driving cycle for a heavy-duty diesel engine. Journal of Mechanical Science and Technology, 27(12), 3893-3902.

Palacios, J., 1999. Understanding and Quantifying Motor Vehicle Emissions with Vehicle Specific Power and TILDAS Remote Sensing. Doctor of Philosophy, Massachusetts Institute of Technology, Boston-USA.

Prati, M. V., Meccariello, G., Della Ragione, L. and Costagliola, M. A., 2015. Real Driving Emissions of a Light-Duty Vehicle in NaplesInfluence of Road Grade. SAE International $12^{\text {th }}$ International Conference on Engines \&
Vehicles, September 2015, Naples, Italy, SAE 2015-24-2509

UITP, 2014, International Association of Public. Bus Systems in Europe - Current Fleets and Future Trends.

Wang, A., Ge, Y., Tan, J., Fu, M., Shah, A. N., Ding, Y., Zhao, H. and Liang, B., 2011. On-road pollutant emission and fuel consumption characteristics of buses in Beijing. Journal of Environmental Sciences, 23(3), 419-426.

Yao, Z., Wei, H., Liu, H. and Li, Z., 2013. Statistical Vehicle Specific Power Profiling for Urban Freeways. Procedia - Social and Behavioral Sciences, 96, 2927-2938.

Yu, Q. and Li, T., 2014. Evaluation of bus emissions generated near bus stops. Atmospheric Environment, 85, 195-203.

Yu, Q., Li, T. and Li, H., 2016. Improving urban bus emission and fuel consumption modeling by incorporating passenger load factor for real world driving. Applied Energy, 161(Supplement C), 101-111.

Zhang, Q., Wu, L., Yang, Z., Zou, C., Liu, X., Zhang, K. and Mao, H., 2016. Characteristics of gaseous and particulate pollutants exhaust from logistics transportation vehicle on real-world conditions. Transportation Research Part D: Transport and Environment, 43, 40-48.

URL-1, from https://www.avl.com/real-drivingemissions-rde-, 13 September 2018

URL-2,

https://ec.europa.eu/clima/policies/transport/veh icles/heavy_en, 13 September 2018 